Nevada

Environmental

Restoration

Project

Corrective Action Plan for

Corrective Action Unit 224:

Decon Pad and Septic Systems

Nevada Test Site, Nevada

Controlled Copy No::

Revision: 0

July 2006

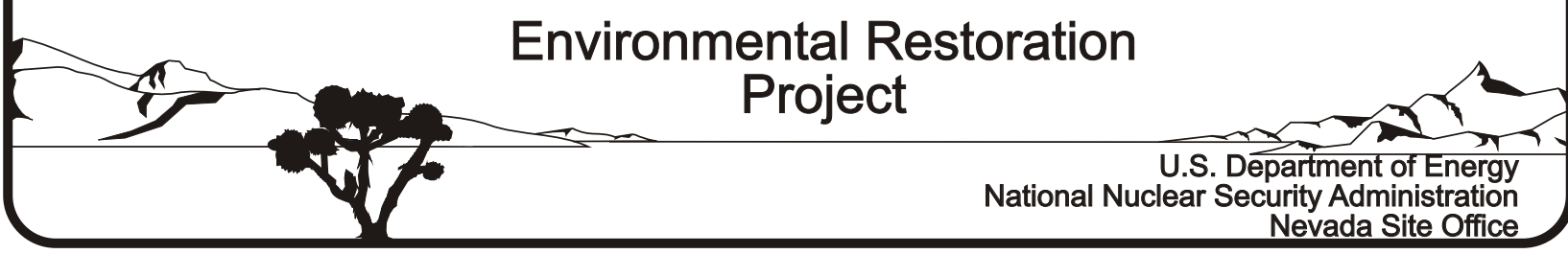




\title{
DISCLAIMER
}

Reference herein to any specific commercial product, process, or service by trade name, trademark, manufacturer, or otherwise, does not necessarily constitute or imply its endorsement, recommendation, or favoring by the United States Government or any agency thereof or its contractors or subcontractors.

This report has been reproduced directly from the best available copy.

Available for sale to the public from:

\author{
U.S. Department of Commerce \\ National Technical Information Service \\ 5285 Port Royal Road \\ Springfield, VA 22161-0002 \\ Telephone: (800) 553-6847 \\ Fax: (703) 605-6900 \\ E-mail: orders@ntis.gov \\ Online ordering: http://www.ntis.gov/ordering.htm
}

Available electronically at http://www.osti.gov/bridge.

Available for a processing fee to the U.S. Department of Energy and its contractors, in paper, from:

\author{
U.S. Department of Energy \\ Office of Scientific and Technical Information \\ P.O. Box 62 \\ Oak Ridge, TN 37831-0062 \\ Telephone: (865) 576-8401 \\ Fax: (865) 576-5728 \\ E-mail: reports@adonis.osti.gov
}




\title{
CORRECTIVE ACTION PLAN FOR CORRECTIVE ACTION UNIT 224: DECON PAD AND SEPTIC SYSTEMS NEVADA TEST SITE, NEVADA
}

\author{
U.S. Department of Energy \\ National Nuclear Security Administration \\ Nevada Site Office \\ Las Vegas, Nevada
}

Controlled Copy No.

Revision: 0

July 2006 
THIS PAGE INTENTIONALLY LEFT BLANK 


\section{CORRECTIVE ACTION PLAN FOR CORRECTIVE ACTION UNIT 224: DECON PAD AND SEPTIC SYSTEMS NEVADA TEST SITE, NEVADA}

Environmental Restoration Project

Approved By:

Janet L. Appenzeller-Wing,

Federal Project Director

Environmental Restoration Project 
THIS PAGE INTENTIONALLY LEFT BLANK 


\section{TABLE OF CONTENTS}

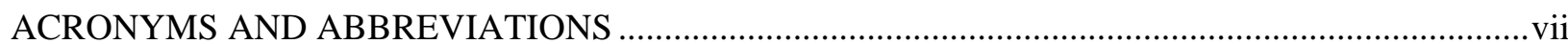

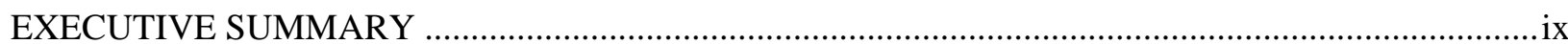

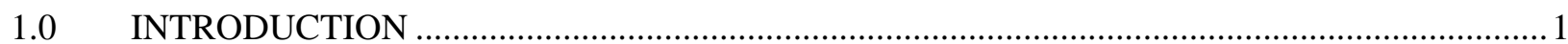

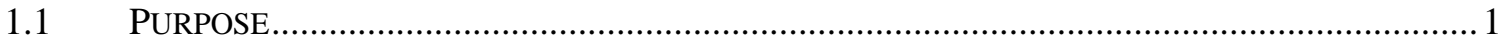

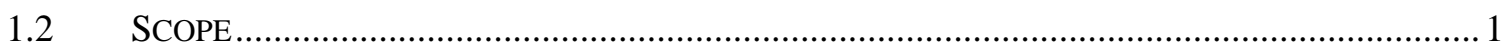

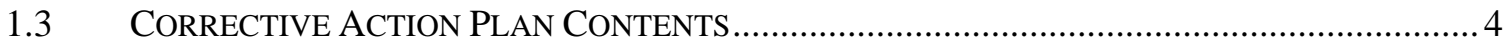

2.0 DETAILED STATEMENT OF WORK

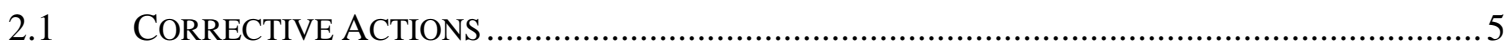

2.1.1 Alternative 1 - No Further Action........................................................................ 5

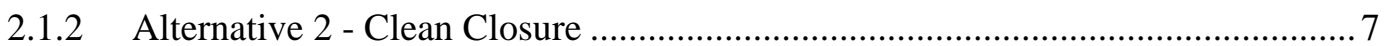

2.2 CONSTRUCTION QUALITY ASSURANCE / QUALITY CONTROL ......................................... 13

2.2.1 Construction Field Sample Collection Activities ................................................... 13

2.2.2 Construction Laboratory/Analytical Data Quality Indicators ............................... 13

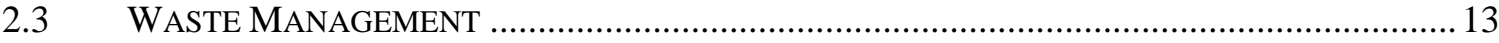

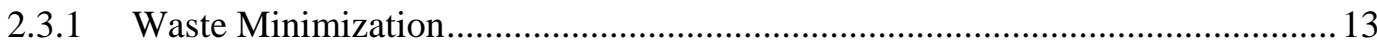

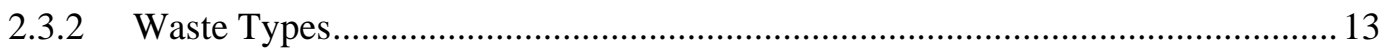

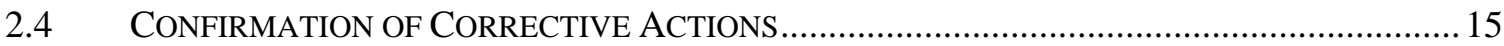

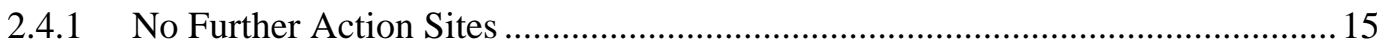

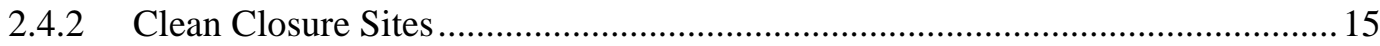

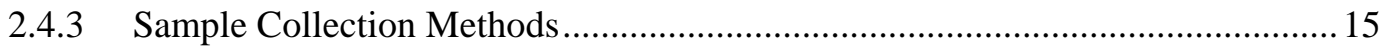

2.4.4 Laboratory/Analytical Data Quality Indicators .................................................. 16

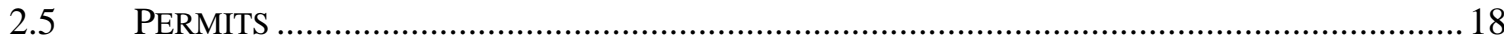

2.5.1 National Environmental Policy Act Checklist.................................................... 18

2.5.2 NNSA/NSO Real Estate/Operations Permit .................................................... 18

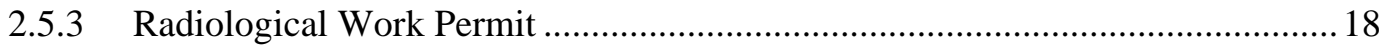

2.5.4 Utility Clearances, Excavation Permits, and Blind Penetration Permits .............. 18

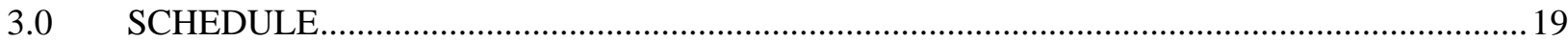

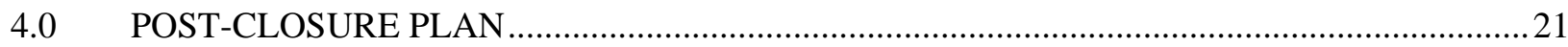

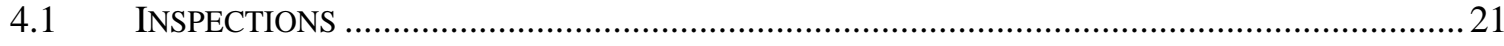

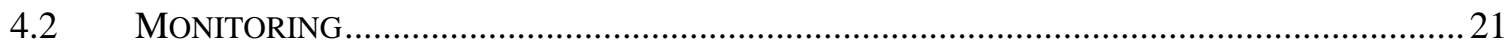

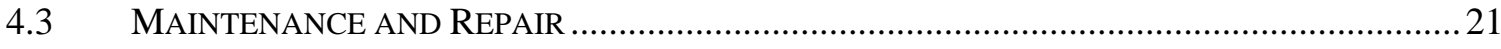

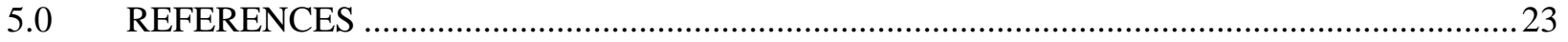




\section{FIGURES}

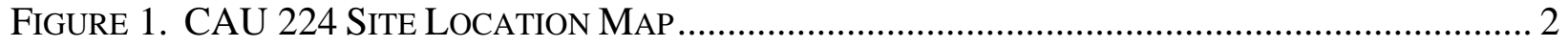

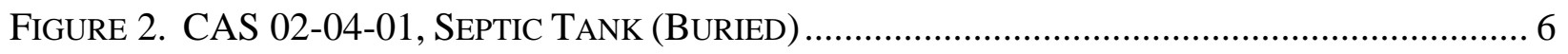

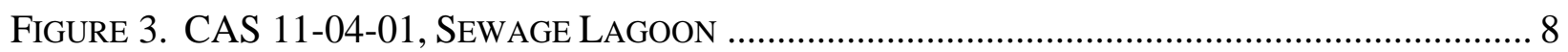

FIGURE 4. CAS 05-04-01, SEPTIC TANKS (4)/DisCHARGE AREA............................................... 9

Figure 5. CAS 06-05-01, LEACHFIELD; CAS 06-17-04, DECON PAD AND Wastewater CATCh; AND CAS 06-23-01, DeCon PAD Discharge PiPING .......... 11

\section{APPENDICES}

APPENDIX A.1 Engineering Specifications and Drawings

APPENDIX A.2 Sampling and Analysis Plan

APPENDIX A.3 Project Organization

LIBRARY DISTRIBUTION LIST 


\section{ACRONYMS AND ABBREVIATIONS}

bgs

BMP

CADD

CAIP

CAP

CAS

CAU

COC

CR

DOE

DQI

DQO

DRO

EPA

FAL

FFACO

$\mathrm{ft}$

ISOCS

LLW

$\mathrm{mg} / \mathrm{kg}$

NAC

NNSA/NSO

NNSA/NV

NSTec

NTS

OI

$\mathrm{OP}$

$\% \mathrm{R}$

PPE below ground surface

best management practice

Corrective Action Decision Document

Corrective Action Investigation Plan

Corrective Action Plan

Corrective Action Site(s)

Corrective Action Unit(s)

contaminant(s) of concern

Closure Report

U.S. Department of Energy

Data Quality Indicator(s)

Data Quality Objective(s)

diesel-range organics

U.S. Environmental Protection Agency

Final Action Level(s)

Federal Facility Agreement and Consent Order

foot (feet)

In-Situ Object Counting System

low-level waste

milligram/kilogram

Nevada Administrative Code

U.S. Department of Energy, National Nuclear Security Administration Nevada Site Office

U.S. Department of Energy, National Nuclear Security Administration Nevada Operations

National Security Technologies

Nevada Test Site

Organization Instruction(s)

Organization Procedure(s)

percent recovery

personal protective equipment 


\section{ACRONYMS AND ABBREVIATIONS (continued)}

$\begin{array}{ll}\mathrm{Pu} & \text { Plutonium } \\ \text { QA/QC } & \text { Quality Assurance/Quality Control } \\ \text { RCT } & \text { Radiological Control Technician } \\ \text { RESRAD } & \text { Residual Radiation } \\ \text { RPD } & \text { relative percentage difference } \\ \text { RWP } & \text { Radiological Work Permit } \\ \text { TCLP } & \text { toxicity characteristic leaching procedure } \\ \text { TPH } & \text { total petroleum hydrocarbons } \\ \mu \mathrm{g} / \mathrm{kg} & \text { microgram/kilogram } \\ \text { WGS } & \text { Waste Generator Services } \\ \mathrm{yd}^{3} & \text { cubic yard(s) }\end{array}$




\section{EXECUTIVE SUMMARY}

Corrective Action Unit (CAU) 224, Decon Pad and Septic Systems, is listed in the Federal Facility Agreement and Consent Order (FFACO) of 1996 (FFACO, 1996). CAU 224 consists of nine Corrective Action Sites (CASs) located in Areas 2, 3, 5, 6, 11, and 23 of the Nevada Test Site (NTS), which is located approximately 65 miles northwest of Las Vegas, Nevada. CAU 224 is comprised of the following nine CASs:

- 02-04-01 Septic Tank (Buried)

- 03-05-01 Leachfield

- 05-04-01 Septic Tanks (4)/Discharge Area

- 06-03-01 Sewage Lagoons (3)

- 06-05-01 Leachfield

- 06-17-04 Decon Pad and Wastewater Catch

- 06-23-01 Decon Pad Discharge Piping

- 11-04-01 Sewage Lagoon

- 23-05-02 Leachfield

Site characterization of the CAU 224 CASs was performed in 2004 and the results are presented in the CAU 224 Corrective Action Decision Document (CADD) (U.S. Department of Energy, National Nuclear Security Administration Nevada Site Office, 2005). Briefly, the results of the site characterization and the scope of work required to implement the recommended closure alternatives include the following:

- CAS 02-04-01, Septic Tank (Buried), is located in Area 2 of the NTS and consists of one buried septic tank and associated piping which previously serviced the Area 2 support facility. No further action is required for this CAS because no contaminants of concern (COCs) were found above the Final Action Levels (FALs). As a best management practice (BMP), the septic tank and distribution box will be removed and disposed appropriately, and associated piping left in place will be sealed. Any manholes will be backfilled to prevent any future accumulation of waste.

- CAS 03-05-01, Leachfield, is located in Area 3 of the NTS in the Subdock complex. No COCs were identified above FALs; therefore, no further action is required for this CAS.

- CAS 05-04-01, Septic Tanks (4)/Discharge Area, is located in Area 5 of the NTS and consists of four septic tanks and associated piping, and a potential overflow area. This CAS will be clean closed by removing a small area of pesticides-contaminated soil ( 2 cubic yards $\left.\left[\mathrm{yd}^{3}\right]\right)$. Liquid and sludge samples in all the tanks showed no COCs. However, as recommended in the CADD, approximately 3,750 gallons of liquid will be removed from each tank and either solidified or containerized in tankers, and disposed appropriately. All septic tanks will be removed and disposed of appropriately, and all associated piping left in place will be sealed. The upstream manholes will be backfilled to prevent any future dumping. As a BMP, approximately $20 \mathrm{yd}^{3}$ of concrete slab supporting the tanks will be removed and disposed appropriately. 


\section{EXECUTIVE SUMMARY (continued)}

- CAS 06-03-01, Sewage Lagoons (3), is located on the Yucca lakebed in Area 6 of the NTS and consists of the former Yucca Lake sewage lagoon systems. No COCs were identified above FALs; therefore, no further action is required for this CAS.

- CAS 06-05-01, Leachfield, CAS-06-17-04, Decon Pad and Wastewater Catch, and CAS 06-23-01, Decon Pad Discharge Piping, comprise a system that was used for decontamination of radiologically contaminated equipment in Area 6 of the NTS. The CASs will be clean closed by removing areas of contaminated soil and concrete. These include a concrete sump $\left(\sim 4 \mathrm{yd}^{3}\right)$ containing sludge $\left(\sim 5 \mathrm{yd}^{3}\right)$ located adjacent to the decon pad, the concrete decon pad $\left(\sim 151 \mathrm{yd}^{3}\right)$, total petroleum hydrocarbon (TPH)-contaminated soil $\left(\sim 337 \mathrm{yd}^{3}\right)$, plutonium (Pu)-239 contaminated soil $\left(\sim 45 \mathrm{yd}^{3}\right)$, and TPH and Pu-239 contaminated soil $\left(\sim 11 \mathrm{yd}^{3}\right)$. The volumes of soil and material are estimates provided in the CADD (NNSA/NSO, 2005) and actual volumes may be different when closure activities are conducted. All waste soil and material generated during site closure will be appropriately managed and disposed.

- CAS 11-04-01, Sewage Lagoon, is located adjacent to the Tactical Demilitarization Development Facility in Area 11 of the NTS and consists of a former sewage lagoon, an evapotranspiration bed, a two-chamber septic tank, and associated piping. COCs were not identified above FALs; therefore, no further action is required for this CAS. As a BMP, a septic tank and distribution box will be removed and disposed appropriately. Associated piping left in place will be sealed. Any manholes will be backfilled to prevent any future accumulation of waste.

- CAS 23-05-02, Leachfield, is located adjacent to Building 753 in Mercury in Area 23 of the NTS. The CAS consists of a leachfield for former Building 155. No COCs were found above FALs; therefore, no further action is required for this CAS. 


\subsection{INTRODUCTION}

Corrective Action Unit (CAU) 224, Decon Pad and Septic Systems, is listed in the Federal Facility Agreement and Consent Order (FFACO) of 1996 (FFACO, 1996). CAU 224 consists of nine Corrective Action Sites (CASs) located in Areas 2, 3, 5, 6, 11, and 23 of the Nevada Test Site (NTS), which is located approximately 65 miles northwest of Las Vegas, Nevada (Figure 1). CAU 224 is comprised of the following nine CASs:

- 02-04-01 Septic Tank (Buried)

- 03-05-01 Leachfield

- 05-04-01 Septic Tanks (4)/Discharge Area

- 06-03-01 Sewage Lagoons (3)

- 06-05-01 Leachfield

- 06-17-04 Decon Pad and Wastewater Catch

- 06-23-01 Decon Pad Discharge Piping

- 11-04-01 Sewage Lagoon

- 23-05-02 Leachfield

Details on site history and site characterization results for CAU 224 are provided in the approved Corrective Action Investigation Plan (CAIP), (U.S. Department of Energy, National Nuclear Security Administration Nevada Site Office [NNSA/NSO], 2004), and the approved Corrective Action Decision Document (CADD) (NNSA/NSO, 2005).

\subsection{PuRPose}

The purpose of this Corrective Action Plan (CAP) is to provide the detailed scope of work required to implement the recommended corrective actions as specified in the approved CAU 224 CADD (NNSA/NSO, 2005).

\subsection{SCOPE}

The results of the site characterization and the scope of work required to implement the recommended corrective action as stated in the CAU 224 CADD (NNSA/NSO, 2005) are briefly discussed below.

CAS 02-04-01, Septic Tank (Buried), is located in Area 2 of the NTS and consists of one buried septic tank and associated piping, which previously serviced the Area 2 support facility. Results for soil and septic tank liquid characterization samples showed no contaminants of concern (COCs) above the Final Action Levels (FALs). No further action is required at this CAS. As a best management practice (BMP), the buried septic tank will be closed per Nevada Administrative Code (NAC) 444.818 (NAC, 2002). The septic tank and a distribution box will be removed and disposed appropriately, and associated piping left in place will be sealed. Any manholes will be backfilled to prevent any future accumulation of waste. 


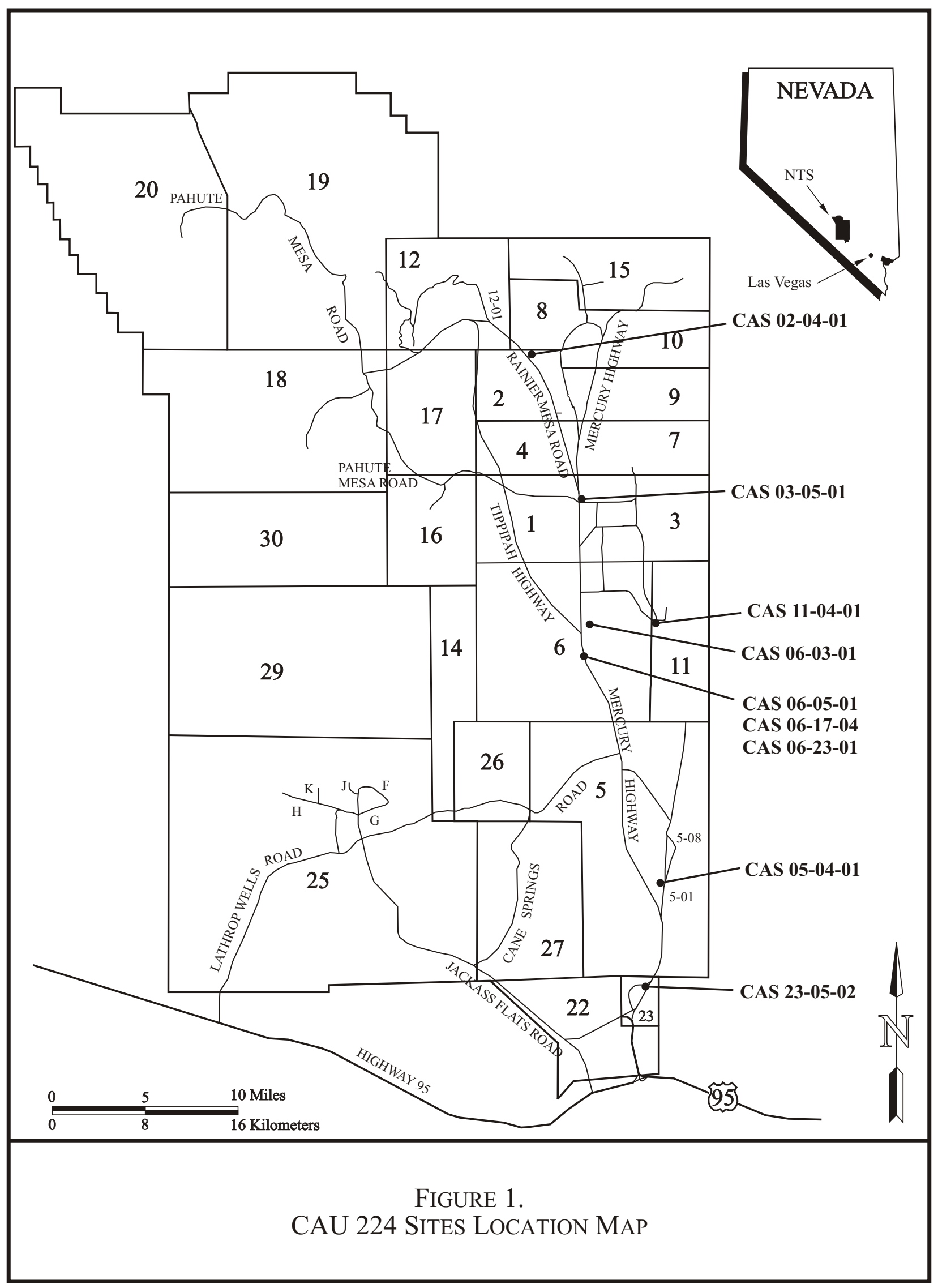


CAS 03-05-01, Leachfield, is located in Area 3 of the NTS in the Subdock complex. The CAS consists of a former leach pit that has been backfilled to grade. Characterization results for soil samples showed no COCs present above FALs. No further action is required for this CAS.

CAS 05-04-01, Septic Tanks (4)/Discharge Area, is located in Area 5 of the NTS and consists of four septic tanks and associated piping, and a potential overflow area. Characterization results indicated a small area of soil contaminated with pesticides. Soil contaminated with pesticides will be removed; verification samples collected, and based on analytical results, the excavated area will be backfilled with NTS native soil. Liquid and sludge samples in all the tanks showed no COCs present above FALs. As a BMP, the contents from each tank will be removed and solidified or containerized in tankers, and disposed of appropriately. All septic tanks will be removed and closed per NAC 444.818 (NAC, 2002). All associated piping left in place will be sealed. Any manholes will be backfilled to prevent any future accumulation of waste. The concrete slab supporting the tanks will be removed and disposed of appropriately.

CAS 06-03-01, Sewage Lagoons (3), is located on the Yucca lake bed in Area 6 of the NTS and consists of the former Yucca Lake sewage lagoon systems. Characterization results of soil samples showed no COCs present above FALs. No further action is required for this CAS.

CAS 06-05-01, Leachfield, CAS-06-17-04, Decon Pad and Wastewater Catch, and CAS 06-23-01, Decon Pad Discharge Piping, comprise a system that was used for decontamination of radiologically contaminated equipment in Area 6 of the NTS. Characterization results for CAS 06-17-04 sludge samples from the sump attached to the decon pad found chemical and radiological analytes present above the FALs. The sump and contents will be removed and disposed appropriately. Additionally, the wastewater sump at CAS 06-17-04, including concrete in the sump area and concrete decon pad, will be removed and disposed appropriately. Total petroleum hydrocarbons (TPH) as diesel-range organics (DRO) and radiologically contaminated soil will be removed from several locations identified in these CASs and disposed of appropriately. After verification sample results show that no COCs remain above the FALs, all excavated areas will be backfilled with NTS native fill.

CAS 11-04-01, Sewage Lagoon, is located adjacent to the Tactical Demilitarization Development facility in Area 11 of the NTS and consists of a former sewage lagoon, an evapotranspiration bed, a septic tank, and associated piping. Characterization results for soil samples showed no COCs above FALs. No further action is required at this CAS. As a BMP, the septic tank and a distribution box will be removed and disposed appropriately, and associated piping left in place will be sealed. Any manholes will be backfilled to prevent any future accumulation of waste.

CAS 23-05-02, Leachfield, is located adjacent to Building 753 in Mercury in Area 23 of the NTS. The CAS consists of a leachfield that serviced former Building 155. Characterization results for soil samples showed no COCs above FALs. No further action is required at this CAS. 


\subsection{Corrective Action Plan Contents}

This CAP is comprised of the following sections and appendices:

- Section 1.0

Introduction

- Section 2.0

Detailed Statement of Work

- Section 3.0

Schedule

- Section 4.0

Post-Closure Plan

- Section 5.0

References

- Appendix A.1

- Appendix A.2

Engineering Specifications and Drawings

- Appendix A.3

Sampling and Analysis Plan

- Library Distribution List

Appendix A.1 is included in this CAP as required by the approved FFACO CAP outline, but contains no material because engineering specifications or drawings are not necessary for closure of CAU 224. Similarly, Appendix A.2 is included as required but contains no material, because sufficient sampling details are provided in Sections 2.1.2 and 2.4.

This report was primarily developed using information and guidance from the following documents:

- Federal Facility Agreement and Consent Order (FFACO, 1996)

- Corrective Action Investigation Plan for Corrective Action Unit 224 (NNSA/NSO, 2004)

- Corrective Action Decision Document for Corrective Action Unit 224 (NNSA/NSO, 2005) 


\subsection{DETAILED STATEMENT OF WORK}

Three corrective action alternatives for CAU 224 were evaluated and identified in the CADD (NNSA/NSO, 2005).

Alternative 1 - No Further Action

Alternative 2 - Clean Closure

Alternative 3 - Close in Place with Administrative Controls

The approved Corrective Actions for the CAU 224 CASs include:

- CAS 02-04-01, No Further Action

- CAS 03-05-01, No Further Action

- CAS 06-03-01, No Further Action

- CAS 11-04-01, No Further Action

- CAS 23-05-02, No Further Action

- CAS 05-04-01, Clean Closure

- CAS 06-05-01, Clean Closure

- CAS 06-17-04, Clean Closure

- CAS 06-23-01, Clean Closure

\subsection{CORREctive Actions}

The corrective action alternatives for CAU 224 were identified in the CADD (NNSA/NSO, 2005) and approved by the Nevada Division of Environmental Protection. The objective of the corrective actions is to prevent or mitigate adverse environmental impacts due to exposure and migration of surface and subsurface contamination. The corrective actions for CAU 224 are identified below.

\subsubsection{Alternative 1 - No Further Action}

No Further Action is the approved corrective action for the following CASs.

CAS 02-04-01, Septic Tank (Buried). No COCs were identified at this CAS during site characterization (NNSA/NSO, 2005); therefore, no corrective actions are required to close this CAS. As a BMP, the septic tank will be closed per NAC 444.818 (NAC, 2002). The septic tank will be opened and any free liquids present will be either solidified in the tank or removed from the tank and solidified (Figure 2). The septic tank and all solidified waste will be removed and transported to an appropriate disposal facility. Any pipes or manholes associated with the tank that are left in place will be sealed/backfilled to prevent any future accumulation of waste. All excavations will be backfilled with NTS native fill and contoured to the approximate surrounding grade. Since no COCs are present at this CAS no verification samples will be collected after removal of the septic tank. 


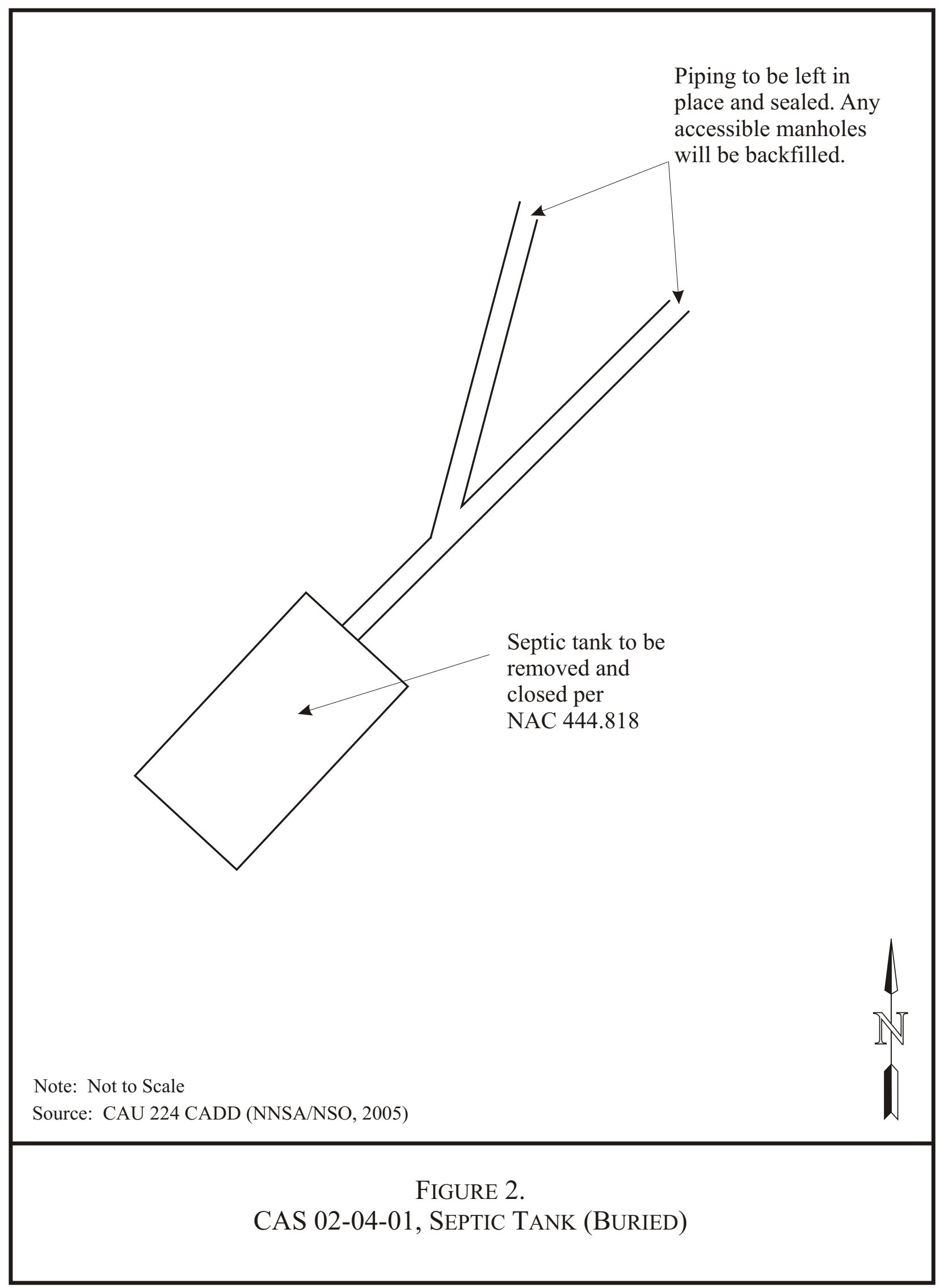


CAS 03-05-01, Leachfield. No COCs were identified at this CAS during site characterization (NNSA/NSO, 2005); therefore, no corrective actions will be conducted at this site.

CAS 06-03-01, Sewage Lagoons (3). No COCs were identified at this CAS during site characterization (NNSA/NSO, 2005); therefore, no corrective actions will be conducted at this site.

CAS 11-04-01, Sewage Lagoon. No COCs were identified at this CAS during site characterization (NNSA/NSO, 2005); therefore, no corrective actions are required to close this CAS. As a BMP, the septic tank will be closed per NAC 444.818 (NAC, 2002). The septic tank and distribution box will be opened and any free liquids present will be either solidified in the tank or removed from the tank and solidified (Figure 3). The septic tank and distribution box will be removed and all solidified waste transported to an appropriate disposal facility. Any pipes or manholes associated with the septic system that are left in place will be sealed/backfilled to prevent any future accumulation of waste. All excavations will be backfilled with NTS native fill and contoured to the approximate surrounding grade. Since no COCs are present at this CAS no verification samples will be collected after removal of the septic tank.

CAS 23-05-02, Leachfield. No COCs were identified at this CAS during site characterization (NNSA/NSO, 2005); therefore, no corrective actions will be conducted at this site.

\subsubsection{Alternative 2 - Clean Closure}

Clean Closure is the approved corrective action for the following CASs.

CAS 05-04-01, Septic Tanks (4)/Discharge Area. CAS 05-04-01 consists of four septic tanks and associated piping, and a potential overflow area. The septic system serviced the former Area 5 Trailer Park.

Characterization results for soil located at the north end of the leachfield showed pesticides are present above FALs (U.S. Environmental Protection Agency [EPA], 2002a) to a depth of 0.5 feet (ft) below ground surface (bgs). Approximately 2 cubic yards ( $\left.\mathrm{yd}^{3}\right)$ of soil $(11 \mathrm{x} 10 \mathrm{x}$ $0.5 \mathrm{ft}$ ), will be removed from an area centered on characterization sample locations C03 and C04 (Figure 4). After the contaminated soil has been removed, a minimum of five verification samples will be collected from the sidewalls and base of the excavation and analyzed for pesticides. Once analytical results verify that pesticides are no longer present above action levels, the excavation will be backfilled with NTS native fill and graded to the surrounding contours. The excavated soil will be placed in appropriate containers and, if necessary, a waste profile will be developed for disposal.

As reported in the CADD, a total of approximately 15,000 gallons of liquid is present in the four septic tanks. Liquid and sludge samples from all the tanks showed no COCs present. Tank 2 did have a positive field screening result for fecal coliform. To protect site workers, a disinfectant will be added to Tank 2 to neutralize any bacteria during closure activities. All septic tanks will be removed and closed per NAC 444.818 (NAC, 2002). The septic tanks will be opened and any free liquids present will be either solidified in the tank or removed from the tank and solidified. The tanks and the solidified contents will be removed and disposed appropriately. 


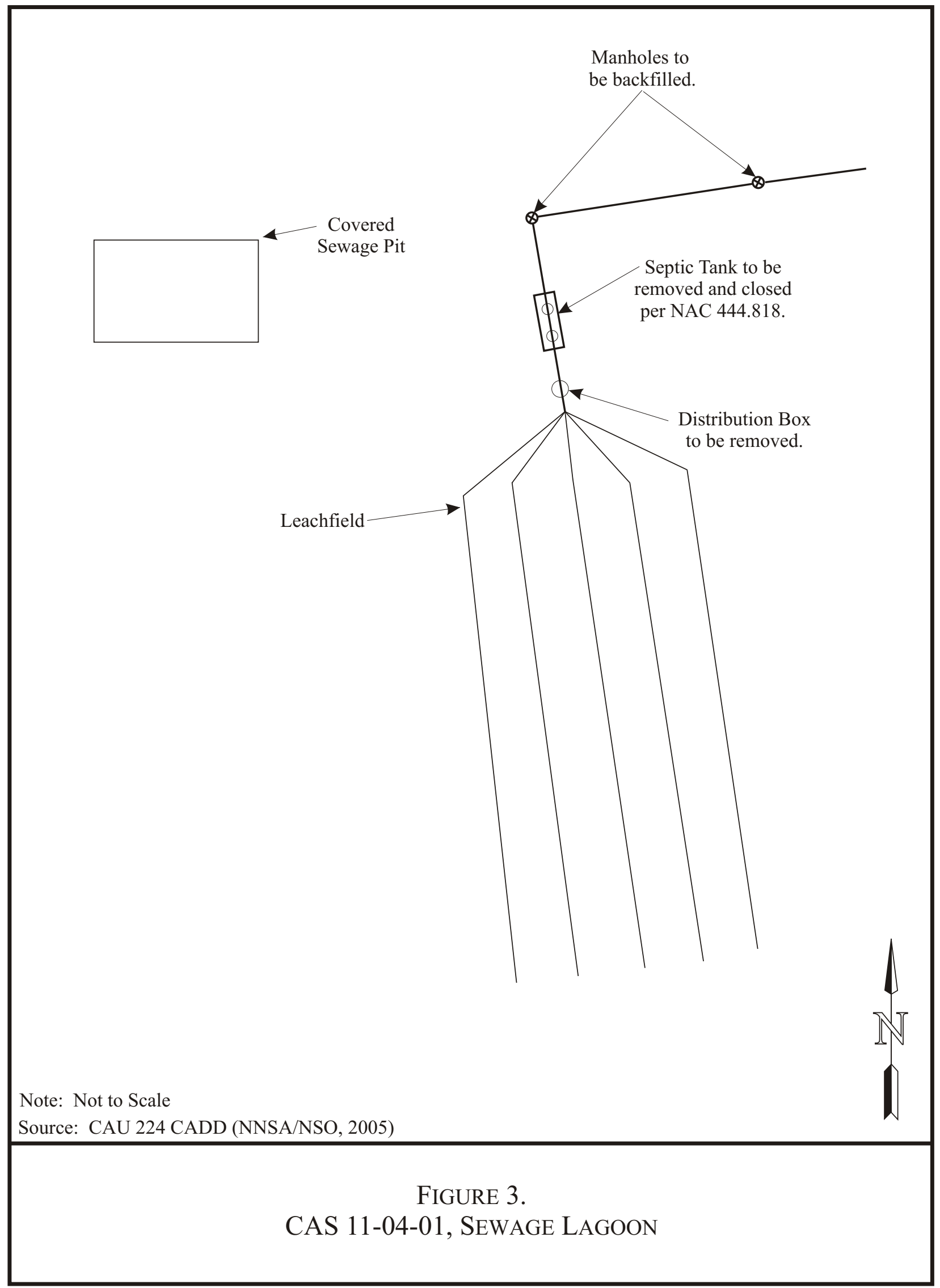




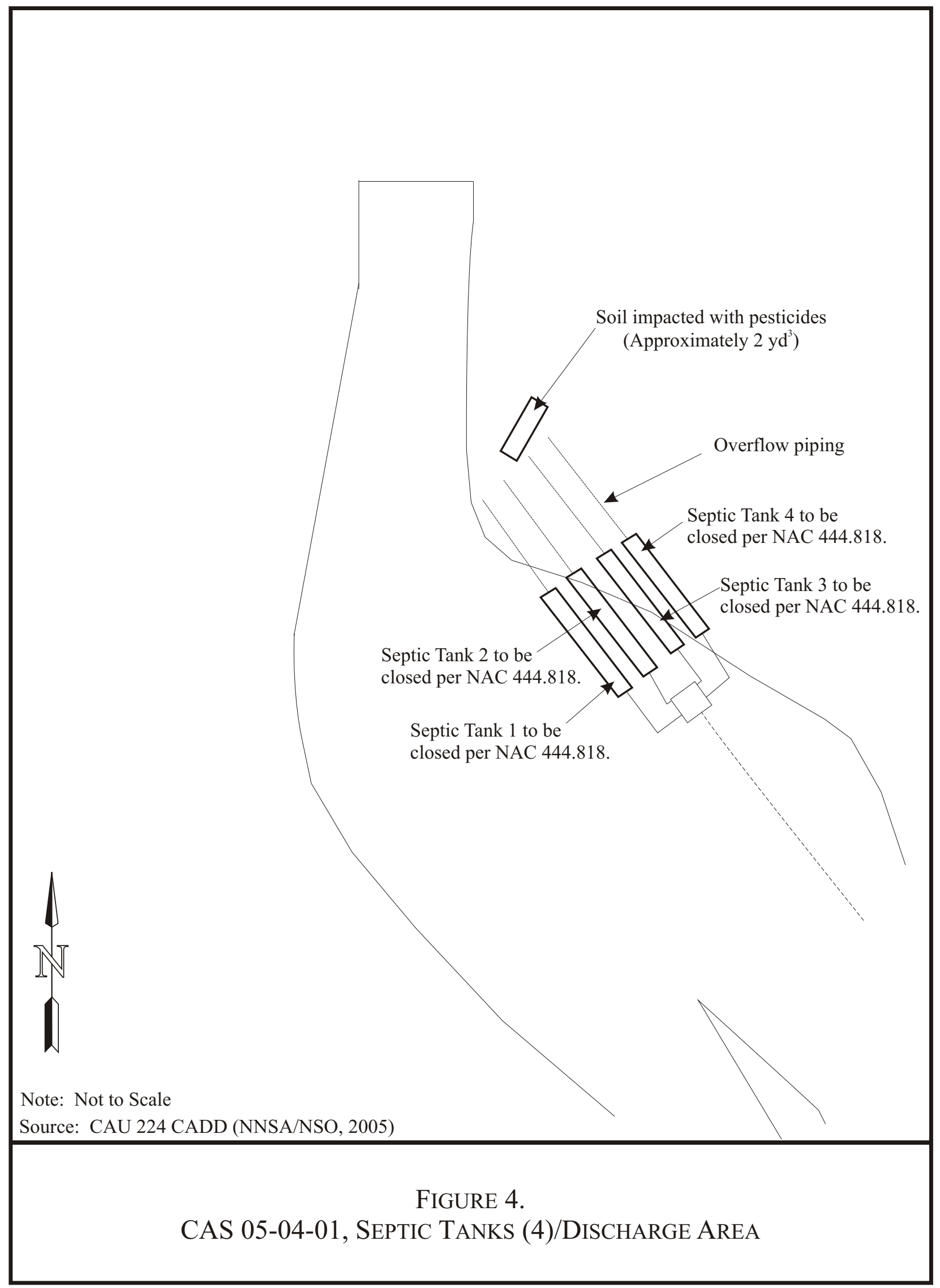


In addition, approximately $20 \mathrm{yd}^{3}$ of concrete slab supporting the tanks will be removed and disposed appropriately. All associated piping and manholes left in place will be sealed/backfilled to prevent any future accumulation of waste. Because no COCs are present at this CAS no verification samples will be collected after removal of the septic tanks.

\section{CAS 06-05-01, Leachfield; CAS 06-17-04, Decon Pad and Wastewater Catch;} and CAS 06-23-01, Decon Pad Discharge Piping. These CASs comprise a system that was used for decontamination of radiologically contaminated equipment in Area 6 of the NTS. CAS 06-05-01 consists of a leachfield and associated sewage lagoons. CAS 06-17-04 is a decon pad used for decontamination of equipment and the associated wastewater catch. CAS 06-23-01 consists of piping connecting the other two CASs to each other and to a former nearby building.

The CASs will be clean closed by removing concrete features and contaminated soils from various areas identified in the CADD (NNSA/NSO, 2005) and shown on Figure 5. Because different COCs are present at distinct areas of the site and because different waste streams will need to be segregated, soil and concrete will be removed from the CASs in the following order:

1. Sludge and concrete in the waste water sump area

2. Area A: plutonium (Pu)-239 and TPH-DRO contaminated soil

3. Areas B and C: Pu-239 contaminated soil

4. Decon concrete pad

5. Areas D, E, F, and G: TPH-DRO contaminated soil

\section{Sludge and Concrete in the Sump Area}

Characterization results for two sludge samples collected from the CAS 06-17-04 waste water sump (Figure 5) attached to the decon pad reported chemical and radiological analytes above the FALs and toxicity characteristic leaching procedure (TCLP) regulatory guidelines (NNSA/NSO, 2005). Approximately $5 \mathrm{yd}^{3}$ of sludge will be solidified in place with NTS native fill or appropriate solidification agent, removed from the sump and managed as potentially mixed waste while it is characterized for disposal. Waste characterization samples will be collected and, based on the COCs reported for the sludge in the CADD (NNSA/NSO, 2005), analyzed for TCLP volatile organics, TCLP semi-volatile organics, TCLP metals, TPH-DRO, polychlorinated biphenyls, gamma emitters, isotopic $\mathrm{Pu}$, and isotopic uranium. Additional analyses may be requested by the disposal facility to support the preparation of a waste disposal profile. In addition, approximately $4 \mathrm{yd}^{3}$ of concrete will be removed from the sump area, radiologically surveyed by In-Situ Object Counting System (ISOCS), and the debris appropriately disposed.

\section{Area A}

Characterization results for soil samples indicated Pu-239 and TPH-DRO above the FALs of 168.1 picoCuries per gram (pCi/g) as determined by the Residual Radiation (RESRAD) evaluation (NNSA/NSO, 2005), and 100 milligrams per kilogram (mg/kg) (NAC, 2003), respectively. Area A is shown in Figure 5. Approximately $11 \mathrm{yd}^{3}$ of contaminated soil will be removed to a depth of $0.5 \mathrm{ft}$ bgs. During soil removal, a Radiological Control Technician (RCT) will survey the soil, equipment, and personnel to determine radioactivity levels. 


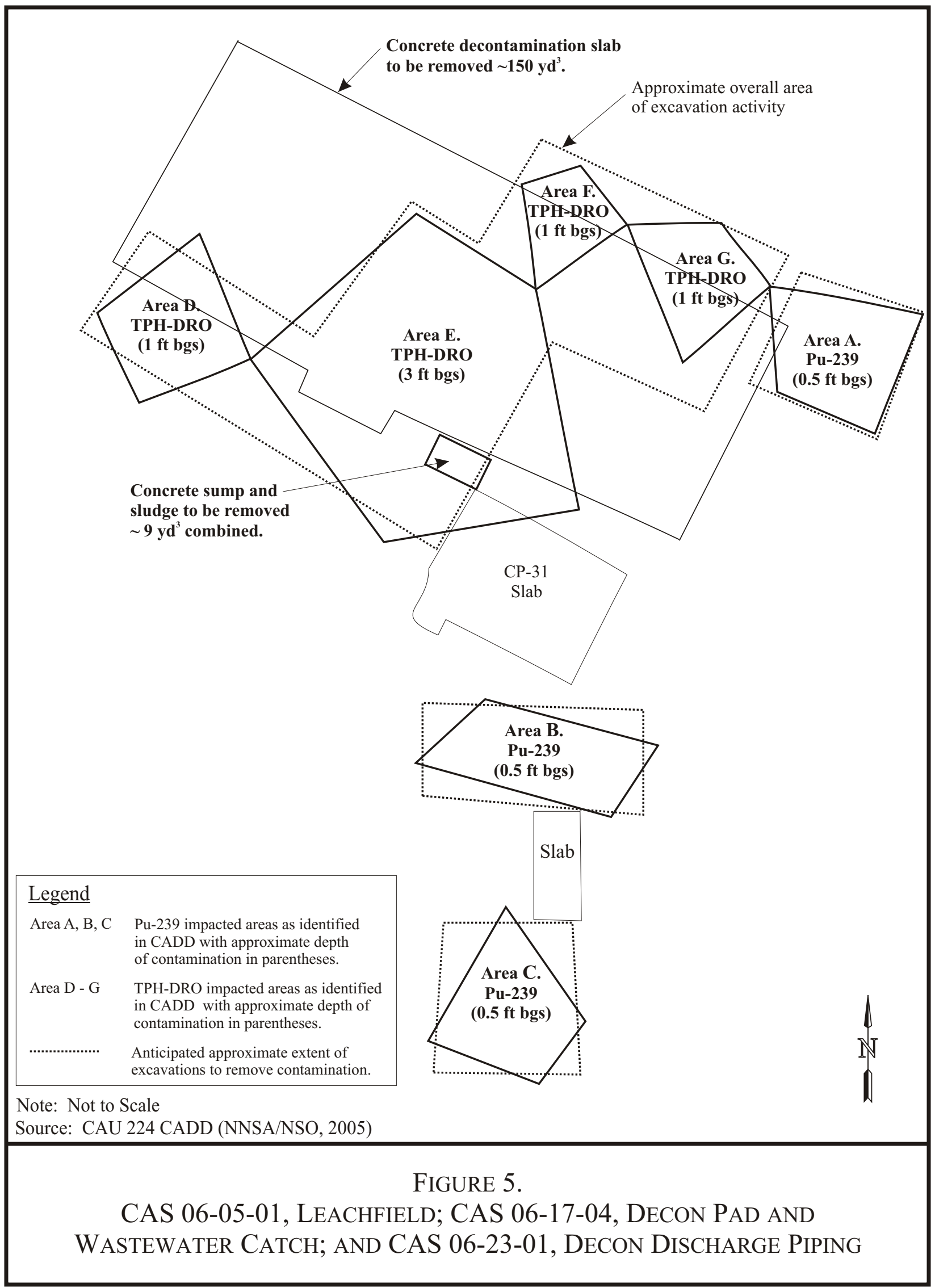


After the planned volume of soil has been removed, field screening for TPH-DRO will be performed using a PetroFLAG ${ }^{\circledR}$ kit or equivalent. Soil removal will continue until field screening indicates that TPH-DRO is no longer present above the FAL. Then a minimum of two soil verification samples will be collected from the base of each excavation. Samples will be analyzed for TPH-DRO, and isotopic Pu to verify that the contaminated soil has been removed below the actions levels. Excavated areas will be backfilled with NTS native fill. Contaminated soil will be placed in appropriate containers. A waste disposal profile will be developed by National Security Technologies (NSTec) Waste Generator Services (WGS) and, based on results, disposed of appropriately.

\section{Areas B and C: Pu-239 Contaminated Soil}

Characterization results for soil samples in Areas B and C indicated Pu-239 above the FAL of $168.1 \mathrm{pCi} / \mathrm{g}$ determined by RESRAD evaluation (NNSA/NSO, 2005). Contaminated Areas B and $\mathrm{C}$ are shown in Figure 5. Approximately $12 \mathrm{yd}^{3}$ and $33 \mathrm{yd}^{3}$ of contaminated soil to a depth $0.5 \mathrm{ft}$ bgs will be removed from Areas B and C, respectively. During soil removal, an RCT will survey the soil, equipment, and personnel to determine radioactivity levels. All radiological surveys will be conducted in accordance with the applicable Company Directives, Radiological Operations, Organization Instructions (OI), and Organization Procedures (OP). After the planned volume of soil has been removed, a minimum of two verification samples will be collected from each area. Samples will be analyzed for isotopic Pu, to verify that cleanup criteria have been met. Contaminated soil will be containerized and managed appropriately. If necessary, a waste profile for disposal will be prepared using radiological data from the CADD and/or by collecting and analyzing waste characterization samples.

\section{Concrete Decontamination Pad}

The soil underneath the concrete decontamination pad is impacted with TPH-DRO (NNSA/NSO, 2005). To access the soil beneath the pad, the concrete pad will be demolished and the debris removed, using appropriate equipment. Approximately $150 \mathrm{yd}^{3}$ of debris will be generated. The concrete debris will be staged on site or placed in appropriate containers and radiologically surveyed. If the debris is free-released, it will be disposed of in the Area 9 U10c Landfill. If the debris does not meet the free-release criteria, a waste disposal profile will be developed and the waste appropriately disposed.

\section{Areas D, E, F, and G}

Characterization results for soil samples from these areas (Figure 5) indicated TPH-DRO above the FAL of $100 \mathrm{mg} / \mathrm{kg}$ (NNSA/NSO, 2005). Estimated volumes for the areas are D ( 21 $\left.\mathrm{yd}^{3}\right)$, $\mathrm{E}\left(\sim 290 \mathrm{yd}^{3}\right), \mathrm{F}\left(\sim 10 \mathrm{yd}^{3}\right)$, and $\mathrm{G}\left(\sim 16 \mathrm{yd}^{3}\right)$. The areas shown in Figure 5 are irregular and were established in the CADD by the location of the closest step-out sample with TPH-DRO concentrations less than the FAL. To facilitate the movement of heavy equipment, the actual excavations are expected to be more regularly shaped. Therefore, it is anticipated that the amount of soil removed from these areas may exceed the $\sim 337 \mathrm{yd}^{3}$ estimated in the CADD (NNSA/NSO, 2005).

Approximately $400 \mathrm{yd}^{3}$ of TPH-DRO impacted soil will be removed from the areas to a depth of $3 \mathrm{ft}$ bgs from these areas. Excavated soil will be placed on plastic or directly into trucks. During excavation, field screening for TPH-DRO will be performed using a PetroFLAG ${ }^{\circledR}$ kit. After field screening indicates that contamination is no longer present above the FAL, a sampling grid with 10-ft spacing will be established over the excavated area. A minimum of one soil 
verification sample from the center of each 10 -ft grid and at least one from each excavation sidewall will be collected and analyzed for TPH-DRO. Once analytical results verify that no TPH-DRO remains above the FAL, the excavation will be backfilled with native fill and graded to the surrounding contours.

\subsection{CONSTRUCTION QUALITY AsSURANCE/QUALITY CONTROL}

Construction activities are limited to excavation, backfilling, solidifying, and removal of liquids from septic tanks, distribution boxes, septic tanks, and associated piping. No engineered structures will be constructed as part of site closure. Therefore, a construction quality assurance/quality control (QA/QC) plan is not required.

\subsubsection{Construction Field Sample Collection Activities}

Construction field samples are not necessary for the closure of the CASs listed in this CAP, although field sample collection activities and radiological surveys will be conducted to verify that clean-up criteria have been met for CAS 05-04-01, Septic Tanks (4)/Discharge Area; CAS 06-05-01, Leachfield; CAS 06-17-04, Decon Pad and Wastewater Catch; and CAS 06-23-01, Decon Pad Discharge Piping. Field sample collection activities are addressed in Sections 2.1.2 and 2.4.

\subsubsection{Construction Laboratory/Analytical Data Quality Indicators}

CAU 224 closure activities are limited to soil removal, non-structural excavation and backfilling, draining of liquid from septic tanks, and removal of septic tanks, distribution boxes, and piping. Therefore, a construction QA/QC plan is not required, and construction Data Quality Indicators (DQI) are not applicable. To ensure that backfill material remains consistent, all fill will be taken from an approved NTS borrow source.

\subsection{WASTE MANAGEMENT}

All waste streams will be managed and disposed of in accordance with applicable state and federal regulations, including U.S. Department of Energy (DOE) Orders, and waste management procedures of the U.S. Department of Transportation, and the contractor. CAU 224 closure activities are expected to generate sanitary waste/construction debris, pesticides, low-level waste (LLW), mixed waste, and hydrocarbon waste. Waste generated during closure activities will be properly managed and shipped to an onsite or offsite facility. Confirmation of waste disposal or transfer to NSTec WGS for management and disposal will be included in the CAU 224 Closure Report (CR).

\subsubsection{Waste Minimization}

All work activities that generate waste will follow the NSTec Waste Minimization and Pollution Prevention Program. Special care will be given to properly characterize and segregate the waste streams to avoid the generation of additional waste.

\subsubsection{Waste Types}

\section{Sanitary Waste}

Sanitary waste (e.g., non-impacted personal protective equipment [PPE] and general trash) and construction debris (e.g., wood, concrete, block, metal, plastic) removed from the site will be 
screened for free release (U.S. Department of Energy, Nevada Operations Office [DOE/NV], 2004) and disposal. Sanitary waste will be disposed of in an onsite permitted landfill.

\section{Hydrocarbon Waste}

All hydrocarbon-contaminated soil will be analyzed for gamma-emitting radionuclides by either ISOCS or laboratory analysis, in order to satisfy the landfill disposal restrictions. Upon receipt of the ISOCS or lab analytical results, the waste will be properly characterized and disposed. Any waste meeting the land disposal restrictions as specified in the landfill permit will be disposed in the Area 6 Hydrocarbon Landfill. Hydrocarbon waste not meeting the landfill disposal restrictions will be stored in a waste accumulation area until a disposal path is identified.

\section{Low-Level Waste}

Closure activities may include removal of radiologically contaminated soil with TPH-DRO. The waste will be characterized by process knowledge, laboratory analysis, and/or radiological screening and a profile for disposal will be prepared. All LLW will be properly characterized by NSTec WGS. All LLW shall be managed and disposed in accordance with NSTec OP-2151.304, "Radioactive Waste Tracking, Handling, and Management at the NTS" (NSTec, 2004a), and all applicable state and federal regulations. All LLW will be packaged in the presence of a Waste Certification Official and WGS personnel according to OP-2151.304 (NSTec, 2004a). LLW will be stored in a radioactive materials area until transport to an appropriate disposal facility can be arranged.

\section{Mixed Waste}

Mixed waste generated during closure activities will be managed and disposed of in accordance with all applicable NSTec and NNSA/NSO procedures and guidelines.

\section{Decontamination Waste}

All radiologically impacted equipment will be surveyed prior to release from the exclusion zone. Any equipment that becomes contaminated during closure activities will be decontaminated on site. Dry decontamination will be the preferred method. For larger pieces of equipment that cannot be effectively decontaminated using dry decontamination techniques, wet decontamination techniques shall be used. All decontamination rinsate will be managed appropriately in accordance with all applicable regulations, and once characterized, properly disposed.

\section{Personal Protective Equipment}

All PPE that becomes contaminated during closure activities shall be disposed with the appropriate waste stream. All wastes generated during closure activities will be properly disposed in either onsite landfills or at a permitted offsite treatment, storage, and disposal facility. 


\subsection{CONFIRMATION OF CORRECTIVE ACTIONS}

Accurate and defensible analytical data will be collected to characterize waste and verify that the closure objectives outlined in this CAP have been met.

\subsubsection{No Further Action Sites}

At five CASs no COC were found and the sites will be closed by taking no further action. The final site condition of these five CASs will be verified by visual inspection and photographic documentation. These CASs include:

- CAS 02-04-01 Septic Tank (Buried). No COC were identified at this CAS. As a BMP, the buried septic tank and a distribution box will be removed and shipped to an appropriate disposal facility, and associated piping will be plugged. Any manholes will be filled to prevent unauthorized dumping in the future.

- CAS 03-05-01 Leachfield. No COC were identified at this CAS.

- CAS 06-03-01 Sewage Lagoons (3). No COC were identified at this CAS.

- CAS 11-04-01 Sewage Lagoon. No COC were identified at this CAS. As a BMP, the septic tank will be closed per NAC 444.818 (NAC, 2002). The septic tank and a distribution box will be removed and shipped to an appropriate disposal facility, and associated piping will be plugged. Any manholes and open piping left in place will be filled/sealed to prevent any future unintentional accumulation of waste.

- CAS 23-05-02 Leachfield. No COC were identified at this CAS.

\subsubsection{Clean Closure Sites}

Section 2.1.2 provides information on verification samples required for the following CASs:

- CAS 05-04-01, Septic Tanks (4)/Discharge Area. Clean Closure

- CAS 06-05-01, Leachfield. Clean Closure

- CAS 06-17-04, Decon Pad and Wastewater Catch. Clean Closure

- CAS 06-23-01, Decon Pad Discharge Piping. Clean Closure

The site will be considered clean closed after laboratory results verify that verification samples are below the applicable action levels. In addition, removal of materials will be confirmed by visual inspection and photographic documentation of final site conditions.

\subsubsection{Sample Collection Methods}

All samples will be collected by qualified Environmental Restoration personnel. Samples will be collected by hand, using disposable pre-cleaned or decontaminated sampling equipment (NSTec, 2000a). Samples will be collected either by hand from the indicated locations, or if the excavation poses a safety hazard to sampling personnel, from the center of a backhoe bucket of soil collected from the indicated locations. Sample collection date, time, and other pertinent information will be logged on a "Chain of Custody Record" form and in a bound project field notebook. 
All samples will be collected in clean containers, labeled appropriately, sealed with a tamper-proof seal, bagged, placed on ice in a cooler, and transported to the Environmental Technical Services group under a "Sample Chain of Custody Record" form (NSTec, 2000b). The Environmental Technical Services group will be responsible for sample management and shipment of the samples to an approved offsite laboratory for analysis. Samples will be analyzed by EPA-approved analytical methods at EPA-approved laboratories (EPA, 1996). Sample analysis will include laboratory analysis of QA/QC samples and will follow stringent QA/QC procedures (EPA, 1996). Sample analysis for radionuclides will be performed in accordance with Environmental Measurements Laboratory Procedures Manuals (DOE, 1997).

All samples will be labeled with a unique sample identification number using the CAS number followed by the sample number (e.g., 061704-V1). Waste characterization samples will be named by using the CAS number followed by the sample number (e.g., 061704-WC1).

One set of QA/QC samples will be collected for every 20 environmental samples or one per sample batch. QA/QC samples will include blind duplicates, and matrix spike/matrix spike duplicates. The blind duplicate will be labeled with a unique sample number.

\subsubsection{Laboratory/Analytical Data Quality Indicators}

Data Quality Objectives (DQO) are qualitative and quantitative statements that specify the quality of the data required to support closure of a site. The DQO for the CAU 224 site investigation were defined in the CAIP (NNSA/NSO, 2004) using the Seven Step DQO Process developed by the EPA (EPA, 2000). Three Conceptual Site Models for the CAU 224 CASs were defined in the CAIP (NNSA/NSO, 2004), and these models were reconciled with the results of the site investigation in the CADD (NNSA/NSO, 2005) (See Appendix A of the CADD). Sample analytical results will be generated during closure activities for CAS 05-04-01, Septic Tanks (4)/Discharge Area; CAS 06-05-01, Leachfield; CAS 06-17-04, Decon Pad and Wastewater Catch; and CAS 06-23-01, Decon Pad Discharge Piping. These CASs will be clean closed and will require the collection and analysis of verification soil samples. All laboratory data generated during closure activities will be reviewed by project personnel to ensure the data are usable and complete according to the CAU 224 DQO. In addition, as specified in the Industrial Sites Quality Assurance Project Plan (U.S. Department of Energy National Nuclear Security Administration/Nevada Operations [NNSA/NV], 2002), 100 percent of the final data packages for verification samples will be evaluated at the Tier I and Tier II levels using applicable NSTec OIs. These include OI-2151.303 (NSTec, 2004b) for validating radiological data, and OI-2154.459 (NSTec, 2003) for validating inorganic chemical data. OI-2154.459 is based on EPA Functional Guidelines (EPA, 2002b). Any data determined not to be valid will be identified in the CR. More details on the proposed number and location of the verification samples are given in Section 2.1.2 of this plan.

DQI are qualitative and quantitative statements that specify the data requirements of a project. The DQI include accuracy, precision, comparability, completeness, representativeness, and sensitivity. These DQI are discussed below. 


\section{Precision}

Precision is a measure of agreement among a replicate set of measurements of the same property under similar conditions. This agreement is expressed as the relative percentage difference (RPD) between duplicate measurements (EPA, 1996). Precision applies to parameters sampled and analyzed in duplicate.

One duplicate sample will be collected per set of 20 or fewer verification samples. All duplicate samples will be collected from the same medium and analyzed for the same set of analytes as verification samples. The precision of the analytical results will be assessed by calculating the RPD for a verification sample and its duplicate sample results. An RPD of less than or equal to 30 percent indicates acceptable precision (NNSA/NV, 2002).

\section{Accuracy}

Accuracy is a measure of the closeness of an individual measurement or the average of a number of measurements to the true value. Accuracy includes a combination of random error (precision) and systematic error (bias) components that result from sampling and analytical operations. This closeness is expressed as percent recovery (\%R) (EPA, 1996). Accuracy will be assessed by examining the \%R of laboratory control and spiked samples. A \%R within the range of 70 to 130 percent indicates satisfactory analytical accuracy (NNSA/NV, 2002).

\section{Representativeness}

Representativeness is a qualitative evaluation of measurement system performance. It is the degree to which sample data accurately and precisely represent a characteristic of a population, parameter variations at a sampling point, or an environmental condition (EPA, 1996).

Representativeness will be attained by ensuring that the sample locations, analytical parameters, analytical methods, sampling protocols, and sample handling all meet the project-specific objectives.

\section{Comparability}

Comparability is a qualitative measure that expresses the confidence that one data set can be compared to another. It will be achieved by using standardized field sampling procedures. The same analytical laboratory will perform the same analyses for all samples. Sample results will be reported in standard units to allow for comparison of the data.

\section{Completeness}

Completeness is a quantitative measure of data quality expressed as the percentage of valid data obtained that satisfies the project-specific requirements. Since a limited number of samples will be collected for both waste characterization and verification of closure, 100 percent of the data collected needs to be of acceptable quality to maintain acceptable QA/QC standards.

\section{Sensitivity}

Sensitivity is the capability of a method or instrument to discriminate between measurement responses representing different levels of a variable of interest. This indicator is determined from the value of the standard deviation at the concentration level of interest. It represents the

minimum difference of concentration that can be distinguished between two samples with a high 
degree of confidence. Sensitivity must be sufficient to detect contaminants at or below decision levels. Sensitivity will be achieved by analyzing all samples using appropriate EPA-approved analytical laboratories, methods, and instruments.

\subsection{Permits}

Prior to beginning field closure activities, planning documents and permits will be prepared. These documents will include a Field Management Plan, National Environmental Policy Act Checklist, NNSA/NSO Real Estate/Operations Permit, Radiological Work Permit (RWP), NSTec Work Packages, excavation permits, and blind penetration permits.

\subsubsection{National Environmental Policy Act Checklist}

A National Environmental Policy Act Checklist will be completed prior to all excavation activities at the site. Excavation activities will follow all applicable federal, state, and local laws, regulations, and permits regarding protection of the environment.

\subsubsection{NNSA/NSO Real Estate/Operations Permit}

A Real Estate Operations Permit will be obtained prior to beginning closure activities. The permit will establish the NNSA/NSO as the prime authority possessing control of the site.

\subsubsection{Radiological Work Permit}

RWPs will be required for work at any radiologically impacted site when radiological conditions require, as determined by NSTec Health Physics. RWPs will inform workers of the specific PPE necessary to protect them while performing their tasks and identify site-specific controls. The workers will be required to sign the permits and acknowledge their understanding of the requirements before entry into any contamination area, if present. The RWPs will be maintained by the RCT at the entrance to the contamination area. All site workers will be required to be Radiation Worker II trained to perform any work within a radiologically controlled area.

\subsubsection{Utility Clearances, Excavation Permits, and Blind Penetration Permits}

An excavation permit and a blind penetration permit will be obtained prior to beginning any excavation activities. These permits require that a utility clearance be performed. A copy of the permit will be filed onsite throughout the duration of the project. 


\subsection{SCHEDULE}

All preparation and field activities are scheduled for completion in Fiscal Year 2007. The FFACO deadline for the CR is October 31, 2007. Sufficient flexibility has been incorporated into the field schedule to allow for minor difficulties (e.g., weather, equipment failure).

NNSA/NSO shall notify the Nevada Division of Environmental Protection of any condition or event that may impact the project schedule. 
THIS PAGE INTENTIONALLY LEFT BLANK 


\subsection{POST-CLOSURE PLAN}

The approved corrective action alternatives are:

- No Further Action for CAS 02-04-01, CAS 03-05-01, CAS 06-03-01, CAS 11-04-01, and CAS 23-05-02.

- Clean Closure for CAS 05-04-01, CAS 06-05-01, CAS 06-17-04, and CAS 06-23-01.

Neither of these corrective actions requires post-closure monitoring or site inspections.

\subsection{INSPECTIONS}

No post-closure inspection will be required for CAU 224.

\subsection{MONITORING}

No post-closure monitoring will be required for CAU 224.

\subsection{MAINTENANCE AND REPAIR}

Because the CAU 224 CASs will be either closed by taking no further action or clean closed, no post-closure maintenance or repairs are anticipated or required. 
Revision: 0

Date: July 2006

THIS PAGE INTENTIONALLY LEFT BLANK 


\subsection{REFERENCES}

DOE, see U.S. Department of Energy.

DOE/NV, see U.S. Department of Energy/Nevada Operations Office.

EPA, see U.S. Environmental Protection Agency.

FFACO, see Federal Facility Agreement and Consent Order.

Federal Facility Agreement and Consent Order. 1996 (as amended). Agreed to by the State of Nevada, the U.S. Department of Energy, and the U.S. Department of Defense.

NAC, see Nevada Administrative Code.

NNSA/NSO, see U.S. Department of Energy, National Nuclear Security Administration Nevada Site Office.

NNSA/NV, see U.S. Department of Energy, National Nuclear Security Administration Nevada Operations Office.

NSTec, see National Security Technologies.

National Security Technologies. 2000a. "Soil Sampling,” Organization Instruction OI-2152.108, Revision 0. Las Vegas, NV.

National Security Technologies. 2000b. “Sample Chain of Custody,” Organization Instruction OI-2152.100, Revision 0. Las Vegas, NV.

National Security Technologies. 2002. "Service Request and Chain of Custody Record," NSTec-0732. Las Vegas, NV.

National Security Technologies. 2003. “Inorganic Data Verification and Validation,” Organization Instruction OI-2154.459. Las Vegas, NV.

National Security Technologies. 2004a. "Radiological Waste Tracking, Handling, and Management at the NTS,” Organization Procedure OP-2151.304, Revision 5. Las Vegas, NV.

National Security Technologies. 2004b. "Validation of Radiological and Chemical Laboratory Data,” Organization Instruction OI-2151.303. Las Vegas, NV.

Nevada Administrative Code. 2002. NAC 444.818, "Sanitation Limitation and Site Requirements.” Carson City, NV. 


\section{REFERENCES (continued)}

Nevada Administrative Code. 2003. NAC 445A.2272, “Contamination of Soil: Establishment of Action Level.” Carson City, NV.

U.S. Department of Energy. 1997. Environmental Measurements Laboratory Procedures Manual, HASL-300, $28^{\text {th }}$ Ed., Vol. 1. New York, NY.

U.S. Department of Energy, National Nuclear Security Administration Nevada Operations Office. 2002. Industrial Sites Quality Assurance Project Plan, Nevada Test Site, Nevada, , DOE/NV--372, Rev. 3. Las Vegas, NV.

U.S. Department of Energy, National Nuclear Security Administration Nevada Site Office. 2004. Corrective Action Investigation Plan for Corrective Action Unit 224: Decon Pad and Septic Systems, Nevada Test Site, Nevada, DOE/NV--965, Rev. 0. Las Vegas, NV.

U.S. Department of Energy, National Nuclear Security Administration Nevada Site Office. 2005. Corrective Action Decision Document for Corrective Action Unit 224: Decon Pad and Septic Systems, Nevada Test Site, Nevada, DOE/NV--1050, Rev. 0. Las Vegas, NV.

U.S. Department of Energy, Nevada Operations Office. 2004. NV/YMP Radiological Control Manual, DOE/NV/11718-079, Rev. 5. Las Vegas, NV.

U.S. Environmental Protection Agency. 1996. Test Methods for Evaluating Solid Waste Physical/Chemical Methods, SW-846, Third Edition. Washington, D.C.

U.S. Environmental Protection Agency. 2000. Guidance for Data Quality Assessment: Practical Methods for Data Analysis, EPA QA/G-9, EPA/600/R-96/055. Washington, D.C.

U.S. Environmental Protection Agency. 2002a. Region 9 Preliminary Remediation Goals, October, San Francisco, CA.

U.S. Environmental Protection Agency. 2002b. Contract Laboratory Program National Functional Guidelines for Inorganic Data Review, EPA/540/R-94/013. Washington, D.C. 


\section{APPENDIX A.1}

\section{ENGINEERING SPECIFICATIONS AND DRAWINGS}

NOTE: Engineering specifications and drawings are not required for closure of CAU 224. This Appendix is included here as required by the approved Federal Facility Agreement and Consent Order outline for a Corrective Action Plan. 
Revision: 0

Date: July 2006

THIS PAGE INTENTIONALLY LEFT BLANK 


\section{APPENDIX A.2}

\section{SAMPLING AND ANALYSIS PLAN}

NOTE: Sufficient details on the type, number, and location of verification samples to be collected to verify site closure activities have been provided in Sections 2.1.2 and 2.4. This Appendix is included here as required by the approved Federal Facility Agreement and Consent Order outline for a Corrective Action Plan. 
Revision: 0

Date: July 2006

THIS PAGE INTENTIONALLY LEFT BLANK 


\section{APPENDIX A.3}

\section{Project ORganization}


Revision: 0

Date: July 2006

THIS PAGE INTENTIONALLY LEFT BLANK 


\section{PROJECT ORGANIZATION}

For this project, the U.S. Department of Energy, National Nuclear Security Administration Nevada Site Office (NNSA/NSO) points of contact are as follows:

NNSA/NSO Federal Industrial Sites Sub-Project Director: Kevin J. Cabble

Telephone Number: (702) 295-5000

NNSA/NSO Task Manager: Sabine Curtis

Telephone Number: (702) 295-0542

The identification of the project Health and Safety Officer and the Quality Assurance Officer can be found in the appropriate plan. However, personnel are subject to change and it is suggested that the appropriate U.S. Department of Energy Project Manager be contacted for further information. The Task Manager will be identified in the Federal Facility Agreement and Consent Order Monthly Activity Report prior to the start of field activities. 
Revision: 0

Date: July 2006

THIS PAGE INTENTIONALLY LEFT BLANK 
CAU 224 - CAP

Section: Library Distribution

Revision: 0

Date: July 2006

\section{LIBRARY DISTRIBUTION LIST}


CAU 224 - CAP

Section: Library Distribution

Revision: 0

Date: July 2006

THIS PAGE INTENTIONALLY LEFT BLANK 


\section{LIBRARY DISTRIBUTION LIST}

U.S. Department of Energy

National Nuclear Security Administration

Nevada Site Office

Technical Library

P.O. Box 98518, M/S 505

Las Vegas, NV 89193-8518

U.S. Department of Energy

Office of Scientific and Technical Information

P.O. Box 62

Oak Ridge, TN 37831-0062

Southern Nevada Public Reading Facility

c/o Nuclear Testing Archive

P.O. Box 98521, M/S 400

Las Vegas, NV 89193-8521

Manager, Northern Nevada FFACO

Public Reading Facility

c/o Nevada State Library \& Archives

100 N Stewart Street

Carson City, NV 89701-4285
1 (Uncontrolled)

1 (Uncontrolled, electronic copy)

1 (Controlled)

1 (Uncontrolled)

1 (Uncontrolled) 
CAU 224 - CAP

Section: Library Distribution

Revision: 0

Date: July 2006

THIS PAGE INTENTIONALLY LEFT BLANK 